\title{
ANALISIS FAKTOR YANG BERPENGARUH TERHADAP KUALITAS AUDIT
}

\author{
Eko Hariyanto ${ }^{*}$ \\ 1Program Studi Akuntansi, Fakultas Ekonomi dan Bisnis, Universitas Muhammadiyah Purwokerto, \\ Indonesia \\ *Email Coresponding Author: ekoh0361@gmail.com
}

\begin{abstract}
ABSTRAK
Penelitian ini bertujuan untuk menganalisis apakah variabel independensi, akuntabilitas, tekanan waktu dan due profesional care berpengaruh terhadap kualitas audit. Disamping itu juga menganalisis apakah variabel independensi, akuntabilitas, tekanan waktu berpengaruh terhadap due profesional care, selanjutnya menganalisis apakah variabel due profesional care dapat memediasi pada hubungan tersebut.

Data diambil dengan questionare dengan jumlah sampel 38. Sebagai sampel pada penelitian ini mereka adalah auditor yang bekerja pada Kantor Akuntan Publik di Jawa Tengah dan berpengalaman minimal 2 tahun. Semua variabel diukur dengan data ordinal. Analysis data dengan menggunakan Struktural Equation Modelling (SEM) dengan program Partial Least Squares (PLS). Hasil penelitian menunjukkan bahwa variabel independensi dan tekanan waktu tidak berpengaruh terhadap due professional care, sedangkan akuntabilitas berpengaruh positip terhadap due professional care.Variabel independensi dan akuntabilitas berpengaruh positip terhadap kualitas audit, sedangkan tekanan waktu tidak berpengaruh terhadap kualitas audit. Due professional care tidak dapat memediasi pengaruh Independensi, tekanan waktu dan akuntabilitas terhadap kualitas audit.
\end{abstract}

Kata kunci: independensi, akuntabilitas, tekanan waktu, due profesional care, kualitas audit.

\begin{abstract}
The purpose of this study was to analyze whether the variables of independence, accountability, time pressure and due professional care to audit quality affect. Besides that, it also analyzes whether the variables of independence, accountability, time pressure affect due professional care, and then analyze whether the variable due professional care can mediate in the relationship.

Data were taken with a questionnaire with a sample size of 38. As a sample in this study they were auditors who worked at the Public Accounting Firm in Central Java and had at least 2 years experience. All variables are measured on an ordinal scale. Data analysis using Structural Equation Modeling (SEM) with Partial Least Squares (PLS) program.

The results showed that the independence and time pressure variables did not affect due professional care, while accountability had a positive effect on due professional care. Independence and accountability variables had a positive effect on audit quality, while time pressure did not affect audit quality. Due professional care cannot mediate the effect of independence, time pressure and accountability on audit quality.
\end{abstract}

Key word: independence, accountability, time pressure, due professional care, audit quality

\section{PENDAHULUAN}

Laporan keuangan memberikan gambaran dan informasi atas kinerja perusahaan yang diperlukan oleh pihak internal maupun pihak eksternal perusahaan sebagai dasar pengambilan keputusan. Menurut FASB, laporan keuangan perusahaan harus memiliki dua karakteristik penting yaitu relevance dan dapat reliable. Kantor Akuntan Publik untuk menjalankan fungsinya dibutuhkan auditor sebagai pelaksana dalam menjalankan jasa 
yang diberikan untuk memberi jaminan relevan dan dapat diandalkannya laporan keuangan perusahaan, sehingga dapat meningkatkan kepercayaan pihak-pihak bersangkutan terkait perusahaan tersebut. Auditor diberikan kepercayaan oleh pihak manajemen dan pihak ketiga untuk membuktikan laporan keuangan yang disajikan manajemen terbebas dari salah saji material. Kepercayaan ini harus dijaga dengan menunjukan kinerja yang profesional (Wiratama dan Budiartha, 2015).

De Angelo (1981) menjelaskan bahwa kualitas audit sebagai kemungkinan auditor akan menemukan dan melaporkan pelanggaran yang ada pada sistem akuntansi. Sampai saat ini masih terdapat keraguan terhadap akuntan publik oleh pemakai laporan keuangan dikarenakan adanya skandal yang melibatkan akuntan publik.

Dalam penelitian ini terdapat beberapa hal yang dapat mempengaruhi kualitas audit, salah satunya adalah independensi. Menurut Suardinatha dan Wirakusuma (2016), independensi merupakan salah satu faktor terpenting yang harus dimiliki oleh seorang Akuntan Publik untuk melaksanakan pemeriksaan laporan keuangan. Standar Auditing Seksi 200.18 (SA:2013) menyebutkan bahwa independen bagi seorang akuntan publik artinya kemampuan auditor untuk merumuskan suatu opini audit tanpa dapat dipengaruhi.

Kemudian faktor lain yang mempengaruhi kualitas audit adalah tekanan waktu. Penelitian Shintya dkk (2016), menjelaskan bahwa tekanan waktu yang dialami auditor pada pelaksanaan audit juga sangat mempengaruhi kualitas audit. Tingginya tekanan waktu melakukan audit membuat auditor semakin meningkatkan efisiensi pengauditan sehingga seringkali pelaksanaan audit yang dilakukan oleh auditor tidak selalu berdasarkan prosedur dan perencanaan yang sesuai dengan ketentuan yang berlaku.

Faktor yang mempengaruhi kualitas audit selanjutnya adalah akuntabilitas. Menurut Burhanudin (2017), akuntabilitas adalah kualitas dari pekerjaan auditor yang dipengaruhi oleh rasa kebertanggungjawaban yang dimiliki auditor dalam menyelesaikan pekerjaan audit dan independensi auditor, probabilitas auditor untuk melaporkan pelanggaran yang auditor temukan tergantung pada independensi auditor. Akuntabilitas berkaitan dengan sikap keterbukaan (transparasi) dalam kaitan dengan cara kita mempertanggung jawabkan sesuatu dihadapan orang lain. Menurut Vidyantari dan Suputra (2018), auditor dituntut untuk dapat mempunyai integritas yang tinggi, tanggungjawab profesional, mengutamakan kepentingan masyarakat, obyektif dalam bekerja, dan selalu mampu mengembangkan tingkat keahlian dan mutu jasa yang diberikan, dengan kata lain auditor bertanggungjawab atas tata kelola suatu entitas melalui pengawasan strategi dan kewajibannya terkait akuntabilitas, termasuk 
pengawasan atas proses pelaporan keuangan. Menurut Saripudin dkk (2012) menunjukan bahwa akuntabilitas berpengaruh positif terhadap kualitas audit. Hal ini sejalan dengan penelitian Purwanda dan Harahap (2015) yang menunjukan bahwa akuntabilitas berpengaruh positif terhadap kualitas audit.

Selanjutnya faktor yang mempengaruhi kualitas audit pada penelitian ini adalah due professional care. Wiratama dan Budiartha (2015), berpendapat due professional care dapat diartikan sebagai sikap yang cermat dan seksama dengan berpikir kritis serta melakukan evaluasi terhadap bukti audit, berhati-hati dalam tugas, tidak ceroboh saat melakukan pemeriksaan dan memiliki keteguhan untuk melaksanakan tanggungjawab. Menurut Vidyantari dan Suputra (2018), menunjukan bahwa due professional care berpengaruh positif terhadap kualitas audit. Hal ini sejalan dengan penelitian Novela, dkk (2017), menunjukan bahwa due professional care berpengaruh positif terhadap kualitas audit. Hal ini konsisten dengan penelitan yang dilakukan Fitria (2016), yang menunjukan bahwa due professional care berpengaruh positif terhadap kualitas audit, hasil penelitian tersebut sama dengan penelitian yang dilakukan (Wiratama dan Budiartha, 2015) yang menunjukan bahwa due professional care berpengaruh positif terhadap kualitas audit. Menurut Novela dkk (2017), hal tersebut berarti semakin tinggi kehati-hati seorang auditor maka dapat meningkatkan kualitas audit.

Para pemakai laporan keuangan sangat mengharapkan suatu pengambilan keputusan yang tepat berkenaan dengan pengambilan sikap terhadap instansi/ perusahaan lainnya. Alat untuk memperoleh informasi tentang perusahaan lain adalah laporan keuangan yang di terbitkan. Laporan keuangan tersebut akan menjadi lebih terpercaya apabila sudah di audit oleh auditor terutama auditor dari Kantor Akuntan Publik.

Jasa asurance yang diberikan oleh KAP ini sangat dipercaya oleh masyarakat. Oleh karena itu kualitas audit yang dihasilkan oleh para auditor KAP ini perlu di tingkatkan, penelitian ini akan meng- hasilkan temuan berkenaan dengan peningkatan kualitas audit yang dikerjakan para auditor KAP.

$\mathrm{H}_{1}$ : Independensi berpengaruh positip terhadap Due professional care

$\mathrm{H}_{2}$ : Tekanan waktu berpengaruh positip terhadap Due professional care.

$\mathrm{H}_{3}$ : Akuntabilitas berpengaruh positip terhadap Due professional care.

$\mathrm{H}_{4}$ : Independensi berpengaruh positip terhadap kualitas audit

$\mathrm{H}_{5}$ : Tekanan waktu berpengaruh positip terhadap Kualitas Audit

$\mathrm{H}_{6}$ : Akuntabilitas berpengaruh positip terhadap Kualitas audit

$\mathrm{H}_{7}$ : Due professional care berpengaruh positip terhadap kualitas audit. 


\section{METODE}

Populasi dan sampel

Populasi pada penelitian ini adalah seluruh auditor yang bekerja di kantor Akuntan Publik di Jawa Tengah. Jumlah Kantor Akuntan publik yang terdaftar ada 15 KAP, dengan sampel yang mengembalikan dan dapat di olah jumlahnya 38.

Pengukuran dan definisi variabel

Kualitas audit merupakan hal yang paling penting untuk diperhatikan oleh pengguna laporan auditan, karena, opini audit akan menjadi dasar para investor dan calon investor untuk mengambil keputusan. Jika laporan keuangan auditan itu tidak diaudit oleh auditor yang berkualitas, maka opini yang dihasilkan juga tidak berkualitas dan akan menyebabkan kekeliruan pengguna laporan untuk mengambil keputusan (Fachruddin dkk,2017). Adapun indikator kualitas audit menurut Putra (2012) sebagai berikut:

(a). Kesesuaian pemeriksaan dengan standar audit, (b) Kualitas laporan hasil audit.

Independensi juga berarti adanya kejujuran pada diri auditor untuk mempertimbangkan fakta dan adanya pertimbangan yang objektif tidak memihak pada diri auditor dalam merumuskan dan menyatakan pendapatnya (Shintya dkk,2016). Adapun indikator independensi menurut Putra (2012) sebagai berikut: (a) Hubungan dengan klien, (b) Independensi pelaksanaan pekerjaan, (c) Independensi laporan.

Tekanan waktu adalah suatu kondisi auditor mendapatkan tekanan dari tempatnya bekerja untuk dapat menyelesaikan tugasnya sesuai dengan waktu yang telah ditetapkan. Tekanan waktu terdiri dari dua macam, yaitu tekanan anggaran waktu (time budget pressure) dan tekanan batasan waktu (deadline time pressure). Tekanan waktu yang tidak sewajarnya dalam pencapaian anggaran waktu dan biaya banyak terbukti sebagai potensial dari perilaku penurunan kualitas audit (Rizal dan Liyundira, 2016). Adapun indikator tekanan waktu menurut Putra (2012) sebagai berikut: (a) Sikap auditor memanfaatkan waktu audit, (b) Sikap auditor dalam penurunan kualitas audit.

Akuntabilitas adalah dorongan psikologi atau kejiwaan yang mana bisa mempengaruhi auditor untuk mempertanggungjawabkan tindakannya serta dampak yang ditimbulkan akibat tindakannya tersebut kepada lingkungan auditor tersebut melakukan aktivitasnya. Pertanggungjawaban individu tidak hanya berfokus pada tindakan dan keputusan yang diambil tetapi juga atas dampak yang ditimbulkan akibat tindakan dan keputusan yang telah diambil. Adapun indikator akuntabilitas menurut Burhanudin (2016) sebagai berikut: (a) Motivasi, (b) Kewajiban social, (c) Pengabdian pada profesi. 
Due professional care memiliki arti kemahiran profesional yang cermat dan seksama. Standar umum ketiga menghendaki auditor independen untuk cermat dan seksama dalam menjalankan tugasnya. Penerapan kecermatan dan keseksamaan diwujudkan dengan dilakukannya review secara kritis pada setiap tingkat supervise terhadap pelaksanaan audit. Kecermatan dan keseksamaan menyangkut apa yang dikerjakan auditor dan bagaimana kesempurnaan pekerjaan yang dihasilkan. indikator due professional care menurut Singgih dan Bawono (2010) sebagai berikut: (a) Sikap skeptic, (b) Keyakinan yang memadai.

Analisa data dan hipotesis testing

Semua variabel diukur dengan skala ordinal. Metode pengambilan data dengan questionare yang dibagikan kepada respnden. Data diolh dengan menggunakan Struktural Equation Modelling (SEM). Program yang digunakan adalah Partial Least Squares (PLS).

\section{HASIL DAN PEMBAHASAN}

Hasil Olah Data Penelitian

Data yang dapat diolah sebanyak 38 responden dengan gambaran data sebagai berikut pada tabel 2 lampiran. Semua indikator mempunyai standar deviasi yang lebih kecil dibandingkan rata-ratanya. Selanjutnya data diuji validitas dan reliabilitas. Pengujian dengan model Convergent validity dan Discriminant validity. Hasil uji tersebut dapat dilihat pada tabel 3 pada lampiran. Pengujian outer model dapat dilihat pada gambar 1 yang menunjukkan bahwa semua loading faktor sudah memenuhi syarat, yaitu minimal 0,5.

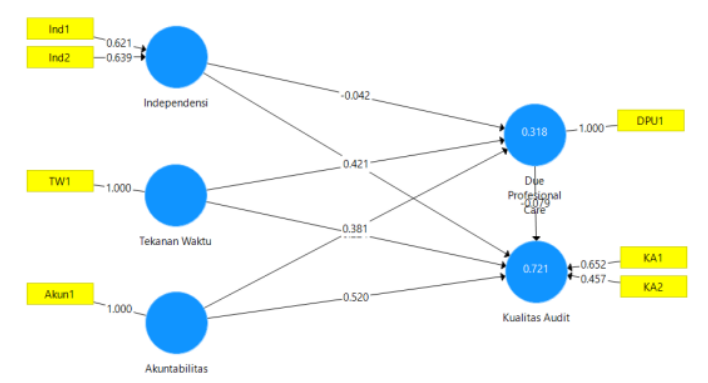

Gambar 1. CFA Indikator Penelitian

Pengujian Hipotesis

Tabel 1. Path Coeffisents

\begin{tabular}{|l|c|c|c|c|c|}
\hline \multicolumn{1}{|c|}{ Variabel } & $\begin{array}{c}\text { Original } \\
\text { Sample } \\
(\mathbf{0})\end{array}$ & $\begin{array}{c}\text { Sample } \\
\text { Mean } \\
\text { (M) }\end{array}$ & $\begin{array}{c}\text { Standard } \\
\text { Deviatio } \\
\text { n } \\
\text { (STDEV) }\end{array}$ & $\begin{array}{c}\text { T } \\
\text { Statistics } \\
\text { (IO/STDE } \\
\text { VI) }\end{array}$ & P Values \\
\hline $\begin{array}{l}\text { Akuntabilitas -> Due } \\
\text { Profesional Care }\end{array}$ & 0.356 & 0.361 & 0.152 & 2.347 & $\mathbf{0 . 0 1 0}$ \\
\hline $\begin{array}{l}\text { Akuntabilitas -> } \\
\text { Kualitas Audit }\end{array}$ & 0.527 & 0.531 & 0.152 & 3.469 & $\mathbf{0 . 0 0 0}$ \\
\hline
\end{tabular}


Analisis Faktor Yang Berpengaruh Terhadap Kualitas Audit

\begin{tabular}{|l|c|c|c|c|c|}
$\begin{array}{l}\text { Due Profesional Care } \\
\text {-> Kualitas Audit }\end{array}$ & -0.142 & -0.127 & 0.175 & 0.807 & $\mathbf{0 . 2 1 0}$ \\
\hline $\begin{array}{l}\text { Independensi - Due } \\
\text { Profesional Care }\end{array}$ & -0.007 & -0.020 & 0.205 & 0.034 & $\mathbf{0 . 4 8 7}$ \\
\hline $\begin{array}{l}\text { Independensi -> } \\
\text { Kualitas Audit }\end{array}$ & 0.446 & 0.443 & 0.151 & 2.945 & $\mathbf{0 . 0 0 2}$ \\
\hline $\begin{array}{l}\text { Tekanan Waktu -> } \\
\text { Due Profesional Care }\end{array}$ & 0.513 & 0.393 & 0.363 & 1.414 & $\mathbf{0 . 0 7 9}$ \\
\hline $\begin{array}{l}\text { Tekanan Waktu -> } \\
\text { Kualitas Audit }\end{array}$ & 0.273 & 0.185 & 0.207 & 1.317 & $\mathbf{0 . 0 9 4}$ \\
\hline
\end{tabular}

$\mathrm{H}_{1}$ : Independensi berpengaruh terhadap Due professional care

Dari tabel tersebut di atas dapat dilihat bahwa nilai $t=0.034$, lebih kecil dibandingkan 1,96 , dan nilai $p$ value menyatakan tidak signifikan ( $p$ value $=0,487$ ).

$\mathrm{H}_{2}$ : Tekanan waktu berpengaruh terhadap Due professional care.

Dari tabel tersebut di atas dapat dilihat bahwa nilai $t=1,414$, lebih kecil dibandingkan 1,96 , dan nilai $p$ value menyatakan tidak signifikan ( $p$ value $=0,079$ ).

$\mathrm{H}_{3}$ : Akuntabilitas berpengaruh positip terhadap Due professional care.

Dari tabel tersebut di atas dapat dilihat bahwa nilai $t=2.347$, lebih besar dibandingkan 1,96 , dan nilai $p$ value menyatakan signifikan ( $p$ value $=0,010$ ).

$\mathrm{H}_{4}$ : Independensi berpengaruh terhadap kualitas audit

Dari tabel tersebut di atas dapat dilihat bahwa nilai $t=2,945$, lebih besar dibandingkan 1,96 dan nilai $p$ value menyatakan signifikan ( $p$ value $=0,002$ ).

$\mathrm{H}_{5}$ : Tekanan waktu berpengaruh terhadap Kualitas Audit

Dari tabel tersebut di atas dapat dilihat bahwa nilai $t=1,317$, lebih kecil dibandingkan 1,96 , dan nilai $p$ value menyatakan tidak signifikan ( $p$ value $=0,094$ ).

$\mathrm{H}_{6}$ : Akuntabilitas berpengaruh terhadap Kualitas audit

Dari tabel tersebut di atas dapat dilihat bahwa nilai $t=3,469$, lebih besar dibandingkan $1,96$ dan nilai $p$ value menyatakan signifikan ( $p$ value $=0,000)$.

$\mathrm{H}_{7}$ : Due professional care berpengaruh terhadap kualitas audit.

Dari tabel tersebut di atas dapat dilihat bahwa nilai $t=0,807$, lebih kecil dibandingkan 1,96 , dan nilai $p$ value menyatakan tidak signifikan ( $p$ value $=0,210$ ).

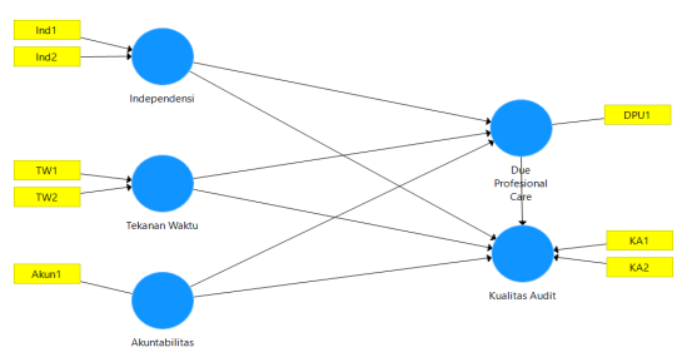

Gambar 2. Diagram Path 


\section{Pembahasan Hasil Analisis}

Variabel Due Profesional Care tidak berpengaruh terhadap Kualitas Audit. Hal ini menunjukkan bahwa Due Profesional Care tidak memediasi variabel independensi, tekanan waktu dan akuntablitas. Bertentangan dengan penelitian yang dilakukan oleh (Wiratama dan Budiartha,2015) yang menyatakan bahwa due professional care berpengaruh positif terhadap kualitas audit. Dalam penelitian Wiratama dan Budiartha menguji secara langsung, bukan sebagai mediasi.

Akuntabilitas berpengaruh positif terhadap Kualitas Audit. Hal ini sejalan dengan penelitian mengenai akuntabilitas yang dilakukan oleh Burhanudin (2017) yang menunujukan hasil bahwa akuntabilitas berpengaruh positif terhadap kualitas audit begitu pula dengan penelitian yang dilakukan oleh (Vidyantari dan Suputra, 2018) menyatakan bahwa akuntabilitas berpengaruh positif terhadap kualitas audit.

Independensi berpengaruh terhadap Kualitas Audit. Hasil penelitian ini sejalan dengan penelitian yang dilakukan oleh Wicaksono (2015) mengungkapkan bahwa independensi memiliki pengaruh yang positif terhadap kualitas audit. Begitupula penelitian dari Suardinatha dan Wirakusuma (2016) juga mengungkapkan bahwa independensi berpengaruh positif terhadap kualitas audit.

Tekanan waktu tidak berpengaruh terhadap Kualitas audit. Penelitian lain ada yang menyatakan bahwa tekanan waktu berpengaruh negatif terhadap Kualitas audit. Seperti penelitian Pikirang dkk (2017) menyatakan bahwa tekanan waktu berpengaruh negatif terhadap kualitas audit hal ini menunjukan jika semakin tinggi tekanan waktu yang diberikan kepada auditor maka kualitas audit menjadi semakin buruk.

Akuntabilitas berpengaruh positip terhadap Due professional care. Tekanan waktu dan independensi tidak berpengaruh terhadap Due professional care. Penelitian tentang faktor-faktor yang secara langsung mempengaruhi Due profesional Care belum ditemukan. Penelitian Hasibuan, Khairul Amri (2019), Independensi tidak berpengaruh terhadap Due professional care. Variabel due professional care dalam penelitian ini tidak dapat memoderasi hubungan antara independensi, perencanaan audit, supervisi audit, akuntabilitas dan integritas dengan kualitas audit pada Kantor Akuntan Publik di Medan.

\section{KESIMPULAN}

Dari hasil analisis dapat disimpulkan sebagai berikut: independensi dan tekanan waktu tidak berpengaruh terhadap due professional care, sedangkan akuntabilitas berpengaruh positip terhadap due professional care. 
Analisis Faktor Yang Berpengaruh Terhadap Kualitas Audit

Variabel independensi dan akuntabilitas berpengaruh positip terhadap kualitas audit, sedangkan tekanan waktu tidak berpengaruh terhadap kualitas audit. Due professional care tidak dapat memediasi pengaruh Independensi, tekanan waktu dan akuntabilitas terhadap kualitas audit.

\section{DAFTAR PUSTAKA}

Burhanudin, Muhammad Alifzuda. (2017). Pengaruh Akuntabilitas dan Independensi Auditor terhadap Kualitas Audit. Jurnal Profita Edisi 6.

De Angelo, L.E. (1981). Auditor Size and Audit Quality. Journal of Accounting and Economics 3 (1981) 183-199.

Eisenhardt M.Kathleen. (1989). Agency Theory: An Assessment and Review. The Academy of Management Review, Vol.14. No.1 Hal:57-74.

Fachruddin Wan, Bahri Syamsul, Pribadi Angelia. (2017). Analisis Faktor yang Mempengaruhi Kualitas Audit dengan Prosedur Audit Sebagai Pemesiasi. Jurnal Ilman, Vol.5, No.2. Hal :1-13.

Fitria, Marisa. (2016). Pengaruh Tekanan Waktu, Due Professional Care, dan Etika Auditor terhadap Kualitas Audit. JOM Fekon Vol.3 No.1.

Ghozali, Imam. (2015). Aplikasi Ananlisis Multivariate dengan Program IBM SPSS 21. Edisi Ketujuh. Semarang: Badan Penerbit Universitas Diponegoro.

Hasibuan, Khairul Amri, (2019), Analisis Faktor-Faktor yang Mempengaruhi Kualitas Audit dengan Due Professional Care Sebagai Variabel Moderating pada Kantor Akuntan Publik di Medan, tesis, Magister Akuntansi, USU.

Kurniawansyah, Deddy. (2017). Auditor Independensi dan Kualitatif Audit. Jurnal Riset Akuntansi dan Bisnis Airlangga Vol. 2. No.1.Hal : 117-134.

Mulyadi. (2014). Auditing Edisi 6. Jakarta:Salemba Empat

Nandari, A.W.S dan Latrini, M.Y. (2015). Pengaruh Sikap Skeptis, Independensi, Penerapan Kode Etik dan Akuntabilitas terhadap Kualitas Audit. E-jurnal Akuntansi Universitas Udayana. Vol.10, No.1 ,Hal: 164-181.

Nirmala dan Latrini. (2017). Pengaruh Keahlian, Tekanan Ketaatan, Tekanan Waktu terhadap Kualitas Audit. E-Jurnal Akuntansi Universitas Udayana Vol.19, No.1, Hal: 683-711.

Novela Tri.T, Sukarmanto Edi, Maemunah Mey. (2017). Pengaruh Due Professional Care, Tekanan Waktu, dan Akuntabilitas terhadap Kualitas Audit. Prosiding Akuntansi. ISSN:2460-6561.

Patrick I.Z, Vitalis Kukeng, Mdoom Iortule. (2017). Effect of Auditor Independence on Audit Quality: A Review of Literature. International Journal of Business and Management Invention. Vol. 6,Issue 3 Hal: 51-59.

Pikirang Julita, Sabijono Harijanti, Wokas H.R.N . (2017). Pengaruh Tekanan Waktu, Independensi dan Etika Auditor terhadap Kualitas Audit. E-jurnal Akuntansi Universitas Udayana. Vol.10, No.1, Hal:91-106.

Purwanda, Eka dan Harahap, E.A. (2015). Pengaruh Akuntabilitas dan Kompetensi terhadap Kualitas Audit. Jurnal Akuntansi/Volume XIX, No. 03 Hal: 357-369

Randal J. Elder, Mark S. Beasley, Arens, Alvin A. Amir Abadi Yusuf (2011). Jasa Audit Dan Jasa Assurance: Pendekatan Terpadu (Adaptasi Indonesia) .; Salemba Empat

Rizal, N dan Liyundira,F.S. (2016). Pengaruh Tekanan Waktu dan Independensi terhadap Kualitas Audit.Jurnal Penelitian Ilmu Ekonomi WIGA Vol. 6 No. 1 Hal: 45 - 52.

Safaroh, Isnaini. (2015). Pengaruh Independensi, Professionalisme, Rotasi KAP dan Anggaran Waktu Terhadap Kualitas Audit. http://ejournal.ukanjuruhan.ac.id. 
Saripudin, Herawaty N, Rahayu. (2012). Pengaruh Independensi Pengalaman, Due Professional Care dan Akuntabilitas terhadap Kualitas Audit.E-Jurnal Binar Akuntansi. Vol. 1, No.1.

Shintya Agneus, Nuryatno Muhammad, Oktaviani.A.A. (2016). Pengaruh Kompetensi, Independensi dan Tekanan Waktu Terhadap Kualitas Audit. Seminar Nasional Cendekiawan. ISSN (E) : 2540 7589.ISSN (P) : 2460-8696.

Singgih, Elisha Muliani dan Icuk Rangga Bawono. (2010). Pengaruh Independensi Pengalaman,Due Professional Care dan Akuntabilitas terhadap Kualitas Audit.SNA XIII UJSP. Purwokerto.

Standar Auditing, (2013). Intitut Akuntan Publik Indonesia. Jakarta : Salemba Empat.

Suardinatha, M.H dan Wirakusuma, M.G. (2016). Pengaruh Independensi dan Professionalisme terhadap kualitas audit. E-Jurnal Akuntansi Universitas Udayana. Vol. 17, No. 3. Desember (2016) Hal: 2503-2530.

Vidyantari, Putu K dan Suputra, I Dewa G.P. (2018). Pengaruh Due Profesional Care, Akuntabilitas dan Kecerdasan Emosional terhadap Kualitas Audit. E-Jurnal Akuntansi Universitas Udayana. Vol.22, No.3. Hal: 2399-2429.

Wicaksono, Monot. (2015). Pengaruh Kompetensi dan Independensi terhadap Kualitas Audit. Jurnal Akuntansi dan Pajak. VOL. 15 NO. 02.

Wijono, Sutarto. (2010). Psikologi Industri dan Organisasi. Jakarta: Kencana.

Wiratama,W.J dan Budiartha, Ketut. (2015). Pengaruh Independensi, Pengalaman Kerja, Due Professional Care dan Akuntabilitas terhadap Kualitas Audit. E-jurnal Akuntansi Universitas Udayana. Vol.10, No.1 , Hal: 91-106 